\title{
«AAprender de las poblanas!». Figuras, imaginarios y prácticas sociales en los versos alrededor del teatro entre los siglos XVIII y XIX
}

\author{
«;Aprender de las poblanas!». Figures, imaginaries \\ and social practices in theatre-related poetry \\ between the $18^{\text {th }}$ and the $19^{\text {th }}$ centuries
}

\author{
Caterina CAMASTRA \\ (Universidad Nacional Autonoma de México) \\ saeeda.bai@gmail.com \\ ORCID ID: 0000-0003-3267-2808
}

\begin{abstract}
This paper examines different types of RESUMEN: Este artículo presenta diferentes textos written poetic texts, both manuscript and printed, that poéticos, tanto impresos como manuscritos, que se circulated in various shapes, formats and media divulgaron por distintos medios, formatos y during the 18th century in New Spain. Beyond soportes (entre los cuales el pliego de cordel) playscripts themselves, texts are related to the theatre durante el siglo XVIII en la Nueva España. Más allá of the time, to poems written by actors and other de los propios textos dramáticos, se trata de textos people in the trade, to showbiz gossip. From these relacionados al teatro de la época, desde las ideas y texts emerge some figures and representations that concepciones acerca del mismo, hasta poemas conforms the New Spain social imaginary. escritos por la misma gente de teatro, pasando por chismes de la farándula. De dichos textos emergen algunas de las figuras y las representaciones que conforman el imaginario social que en ese momento rodeaba el teatro.
\end{abstract}

Keywords: Poetic texts, theatre, New Spain, text PALABRAS-Clave: textos poéticos, teatro, Nueva formats, social imaginary

España, soportes textuales, imaginario social

El aumento de la producción y circulación de impresos en el siglo XVIII, amén de razones prácticas como los avances tecnológicos o el abaratamiento del papel, se origina y articula alrededor de intereses, costumbres, inquietudes, gustos y demandas culturales, así como de los lugares y ambientes que los catalizan. El teatro es uno de esos ambientes. Por un lado, no solo sigue vigente, sino que prolifera la impresión de las obras más exitosas en pliegos de cordel, o bien, de sus más exitosos fragmentos, señal de su prolongado favor entre el público lector (y oidor) de literatura breve: entre la memoria de los espectadores y la letra impresa, el texto dramático se compendiaba, deshebraba y disolvía, alimentando la circulación de tópicos, motivos, personajes y, por ende, el imaginario de la (re)creación colectiva. Por otro lado, entre las compañías teatrales en el XVIII se difunde y afianza la costumbre de mandar a imprimir el guion para venderlo en el teatro el mismo día del estreno. Los datos de la función misma - fecha, teatro, elencosuelen estar incluidos en estas ediciones de circunstancia, entre las cuales destacan los libretti de ópera (que cumplían además la función práctica de apoyar la comprensión del 
texto, ya que el canto operístico la dificulta). Llegados en gran número hasta nosotros en gran medida gracias al fenómeno del coleccionismo, los libretti suelen mostrar, en mayor o menor medida, cierto cuidado de composición visual (figs. 1 y 2). La edición del texto no es siempre esmerada, aunque hay casos, como el que se ilustra, de ediciones incluso bilingües, lo cual denota la valoración y atención del texto, del que no se quiere descuidar ni la versión original ni la inteligibilidad en el lugar donde la ópera se representa (fig. 3). Finalmente, una tercera modalidad de circulación del texto dramático es más bien restringida y exclusiva: el texto en su papel de guion, herramienta para el trabajo de montaje. Tachones y enmiendas sugieren que estos textos no fueron concebidos para su venta y difusión pública (fig. 4).

A menudo nos encontramos frente a una suerte de inversión de la que en algún momento se pensó como la trayectoria «natural» o más bien histórica de la circulación textual, por ende, la «evolución» de sus formas: el paso de la oralidad, al manuscrito, al impreso es un recorrido que aquí se encuentra invertido, del impreso a su copia manuscrita a su oralización en la puesta en escena. Por ejemplo, el repertorio del que proceden las figuras 4 y 5 perteneció a la compañía de Macedonio Espinosa, un maromero novohispano que trabajó entre las postrimerías del siglo XVIII y el principio del XIX, y está en gran parte constituido por copias manuscritas de originales impresos españoles, opción probablemente más económica que adquirir una copia impresa original. No obstante, la finalidad de esas copias manuscritas, los tachones y enmiendas mencionados, se nota a veces un repentino y algo conmovedor afán estético visual del copista: sus versiones a veces lucen detalles que imitan la estética de los impresos, como las grecas decorativas (compárense las imágenes de las portadas de las dos versiones de Las cortesías, manuscrita e impresa, figs. 5 y 6).

La producción de textos alrededor de los escenarios en el siglo XVIII, sin embargo, no se limita a los textos dramáticos. Florece también una miscelánea de versos de circunstancia, versos acerca del teatro, así como versos de autoría de gente del teatro, sobre soportes a veces inusuales, distintos del manuscrito o el impreso en papel. El frecuente empleo del endecasílabo denota ciertas aspiraciones al estilo culto y elevado, característica que se puede observar en varias de las composiciones aquí señaladas. Como conviene a los versos de circunstancia, los poemas producidos como elogio y homenaje para algún personaje o acontecimiento a menudo usan juegos de palabras que denotan la persistencia del gusto barroco por el lucimiento de la destreza lingüística. Uno de esos juegos es el acróstico — que aparece en este soneto más pareado-, que Fernando de Gavila, primer actor y dramaturgo del Coliseo de México en la década de 1790, dedica a Silvestre Díaz de la Vega, juez del teatro; leyendo en vertical las letras iniciales de los versos, se aprecia «Felycýssymos dýas»:

¡Feliz mil bezes el que, generoso,

Encumbrando su nombre hasta la luna,

Logra aplausos de todo virtuoso

Y descubre lo noble de su cuna!

¡Cómo hunís a lo recto lo piadoso!

Ya lo aclama, señor, buestra fortuna,

Siendo de todos yris tan amado,

Siendo de todos sol tan respetado.

Yo, que os admiro savio y tan prudente, 
Me humillo al poderoso, a quien, rendido, Oración hago y ruego que os aumente

Sus dones, que benigno en vos ha unido:

Dilate buestra vida largamente

Y la de buestra esposa, esto le pido.

A ello, señor, estoy siempre obligado,

Siendo Gavila, buestro fiel criado ${ }^{1}$.

También hacen uso del acróstico, más complicado y muy llamativo visualmente (fig. 7) ${ }^{2}$, los versos que repartió la cantarina Inés García la Inesilla unos años más tarde, en 1813 (Olavarría y Ferrari, 1961: 166-168), cuando una función de beneficio ${ }^{3}$ para ella: «Viva de México el público benigno», se lee en vertical, en añadidura al juego de disposición tipográfica con la «a» final de todos los versos. Hablando de soporte, en este caso el poema fue repartido entre la concurrencia, asegura Olavarría y Ferrari, «impreso en seda con letras doradas o en papel blanco con letras rojas» (167): la elección de soportes y tintas se suma a la disposición tipográfica para crear un efecto de novedosa elegancia, dejando en claro la presunción y vanidad de la Inesilla, quien con toda probabilidad quiso esa presentación. Otro soporte textil fue en alguna ocasión el propio telón del teatro, en el que parece que en alguna ocasión alrededor de 1786 lucieron ¿bordadas?, ¿pintadas?, estas estrofas (o alguna de ellas) acerca de la misión del teatro según la ideología neoclásica, versos que Germán Viveros sugiere pudieran también ser de la autoría de Fernando de Gavila (1996: 52, n. 79). La estructura formal es una mezcla de silvas y pareados endecasílabos:
Procuro con ficciones
inclinar hacia el bien los corazones.
La Comedia es mi nombre
y mi deber el corregir al hombre.
Es el Drama mi nombre
y mi dever el corregir al hombre,
haziendo, en mi exercicio,
amable la virtud, odioso el vicio ${ }^{4}$.
Con risa y canto alivio pesadumbres
y de todos corrijo las costumbres.

\footnotetext{
${ }^{1}$ BN-FR, Manuscritos, vol. 1411, fol. 16r. Al revés de la hoja, en la esquina inferior izquierda, de arriba abajo, se encuentra la inscripción dedicatoria: «Al señor don Silbestre Díaz de la Vega, juez director del Coliseo de Mexico. Está A.S.P. el contenido» (fol. 16v). Antes de ser contador general del Tabaco, Díaz de la Vega recibió en 1786, de parte del virrey Bernardo de Gálvez, el encargo de escribir el reglamento de la sociedad de suscriptores del teatro, y en los años siguientes siguió de revisor de obras teatrales (véase Viqueira Albán, 2001: 76-77; Viveros, 1996: 178; Olavarría y Ferrari, 1961: 51).

${ }^{2}$ Se muestra la reconstrucción de Olavarría y Ferrari, ya que el original no ha sido localizado, confiando en que dé una idea más o menos fiel de la disposición textual del poema.

${ }^{3}$ Así se llamaban las funciones cuya ganancia estaba destinada a uno de los miembros de la compañía.

${ }^{4}$ Olavarría y Ferrari señala que esta estrofa formaba parte de la decoración del nuevo telón de embocadura del Coliseo, mandado hacer en el marco de la renovación del teatro patrocinada por el Conde de Gálvez en 1786 (1961: 32).
} 
Ría, llore, cante, embelese, asombre, será mi fin la corrección del hombre.

Con risa y canto moraliso austero que es bella la virtud, el vicio fiero.

En tono honesto, bien jocoso o grave, hago el vicio feroz, la virtud suave.

Con la risa, la burla y con el canto alago la virtud, el vicio espanto ${ }^{5}$.

Dejando los curiosos soportes textiles y volviendo al papel, también cabe señalar que a veces los mismos programas de las funciones, especialmente de las funciones especiales de beneficio, se imprimían en verso. Este, por ejemplo, es un extracto de un programa de 1790:

Dos piezas de cantado primorosas harán los intermedios divertidos, siendo del mejor gusto, y deleitosas, que con placer ofrecen muy rendidos, Las lanchas y Boleras tan graciosas y otros sones del país, ya conocidos, Jarabe y Bergantines cantarán,

las que Acosta y Morales bailarán.

(Olavarría y Ferrari, 1961: 128)

En esta profusión de versos escritos por, para y alrededor del teatro, destaca un sub-género que, desde panfletos y pasquines, pervivirá a lo largo del siglo XIX en forma de nota periodística y representará el antecedente de algo sumamente exitoso en la cultura de masas de los siglos XX y XXI, a saber, los chismes de famosos: hablo de las alabanzas o también su opuesto, las burlas, que tenían por blanco a alguno de los personajes de moda. La siguiente décima espinela, por ejemplo, procede de una sátira manuscrita que circuló en la Nueva España hacia 1789, titulada «Querella contra el estado del Coliseo, representada la acción popular por un hermano de la Cofradía del Recato»:

Por fuerza quieren que guste del Güero los aullidos, de Nicolás los berridos y de Tules el embuste: y aunque a la vista no ajuste su infelice, tibia llama, quiere, quien así lo trama, con novedad bien extraña que represente una araña papel de primera dama. (Olavarría y Ferrari, 1961: 72)

\footnotetext{
${ }^{5}$ BN-FR, Manuscritos, vol. 1411, fols. 10r-11r.
} 
En otras ocasiones los teatreros, al contrario, son enaltecidos por los versos que se les dedican. Pocas décadas después, en la prensa periódica del XIX, aparecerán reseñas de espectáculos en forma de poemas. Los versos que siguen son extraídos de composiciones más largas, casi casi de aliento épico, y proceden respectivamente del Semanario político y literario de México (1821) y El Sol (1823):

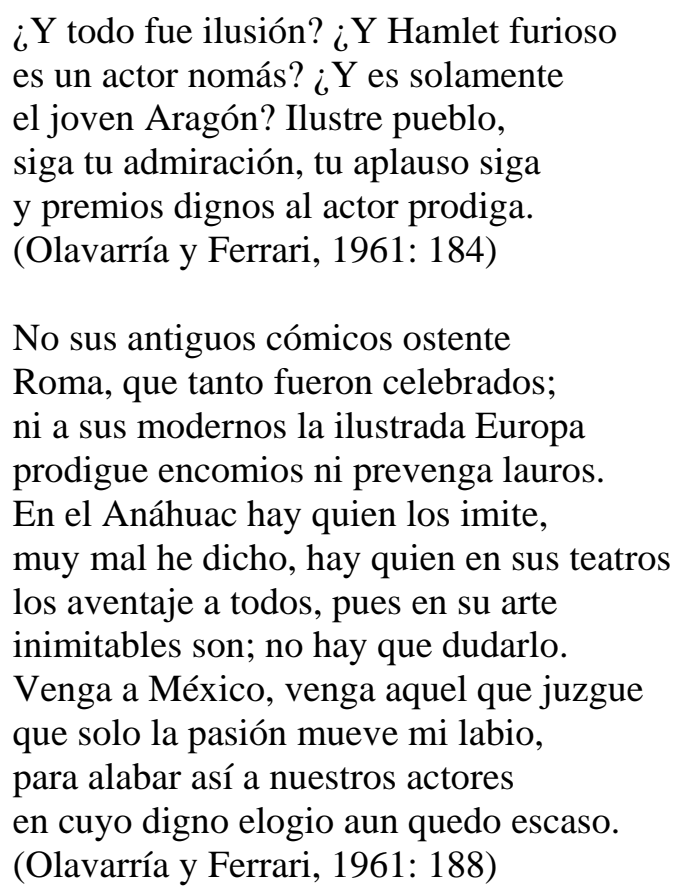

En este último caso, amén de la persistencia de la intención culta en el endecasílabo, trasluce claramente el clima cultural del momento: la reivindicación orgullosa del arte de los teatreros autóctonos se inscribe en el discurso más general de reivindicación de las glorias nacionales, sustento cultural e imaginario de la Independencia mexicana en acto, en plena tarea de componer, inventar sus figuras mitológicas. El aliento épico, finalmente, no se limita a la longitud de las composiciones. Sin embargo, no se trata tanto de que el patrón de construcción de los significados y símbolos del orgullo nacional se haya proyectado sobre la gente de teatro; más bien, al revés, el discurso del nacionalismo independentista acoge e incorpora, para sus propio fines, otro discurso de orgullo, un discurso personal y gremial que se venía fraguando de cierta manera desde hace siglos, para definirse y afirmarse con mayor fuerza en el XVIII: el discurso que subyace a la figura del divo de las tablas. En sociedades que le han visto como un personaje siempre sospechoso, cercano semántica y vivencialmente al mundo engañoso de bufones y merolicos, al margen de lo lícito marcado por las costumbres y las normas sociales, el actor ha luchado por reclamar la dignidad del papel de su propia vida en el teatro del mundo. Como ejemplo tenemos los commedianti dell'Arte italianos del XVII, como Flaminio Scala (Teatro delle favole rappresentative, 1611) y Francesco Andreini (Le bravure del capitan Spavento, 1606), quienes publican sus propias obras, mismas que a menudo delatan la clara intención de trascender lo estrictamente escénico hacia los terrenos de la literatura y hasta de la filosofía, y lo hacen, entre otras razones, por el afán de afirmar su propio estatus como gente letrada, artistas, intelectuales con derecho de piso en la historia no solo de los escenarios, sino también de las literaturas y las ideas. 
En el siglo XVIII, sin embargo, cristaliza y se hace evidente más bien otro aspecto, otra faceta del orgullo gremial teatrero: la figura del divo, consagrado más por el favor del público que por las obras publicadas, que anda por la vida a golpe de desplantes, berrinches y arranques de altanería. En este marco discursivo e imaginario, cobran especial interés, en la Nueva España de finales de siglo, algunos poemas de la autoría de una joven actriz y titiritera poblana, Manuela alias la Lechuga. De entrada, confirman la característica de la gente de teatro, hombres y mujeres, como grupo social y económicamente modesto, sin embargo, letrado, situación algo excepcional para las condiciones de la época. Como a menudo sucede para este tipo de textos literarios populares, llegaron hasta nosotros, paradójicamente, gracias a quienes se afanaron en reprimirlos y retirarlos de la circulación, encerrándolos en polvorientos expedientes, mismos que inesperadamente resultarían ser máquinas del tiempo: en 1794, los poemas de la Lechuga terminarán en manos del Santo Oficio. A diferencia de lo que pasó con muchos sones y coplas, los versos de la joven actriz no fueron denunciados por indecentes, sino que acabaron incautados por razones indirectas, como consecuencia de una denuncia en contra de su amante, un tal José Francisco Delgado, presentada por la esposa de él, Ma. Teresa Echanojáuregui. La mayoría de las composiciones de la actriz son, de hecho, cursis y amaneradas coplas de amor que utilizan varios recursos comunes (como la glosa, por ejemplo), dedicadas al susodicho José Francisco, o bien a otro, u otros, no es dado saber. Sin embargo, dos de los poemas destacan de entre la tópica cursilería de los demás, siendo los que resultan aquí especialmente interesantes. Uno de ellos es un romance, y parece inserto en alguna más amplia controversia entre burlas y elogios al estilo de los libelos y notas periodísticas arriba mencionados. La protagonista es Manuelita, es decir, la misma Lechuga, quien habla de sí misma en tercera persona. No sabemos si su circulación fue en forma manuscrita, tal como se encuentra en el expediente (fíg. 8), o llegó a imprimirse, pero con toda probabilidad sí fue declamado en algún escenario o alguna reunión mundana o en ambos.

Todo empieza con la relación de la representación de alguna de las muchas comedias de santo protagonizadas por santa Bárbara:
De santa Bárbara se hizo una comedia de fama ${ }^{6}$, en lo que huvo que reýr desde la primer jornada. Muchos dijeron, al ber que la hacía la mexicana, que de zedro ${ }^{7}$ no habían visto representar a esta santa ${ }^{8}$.

Sale a relucir aquí uno de los rasgos característicos de ambos poemitas presentados: la mención de la raza y el mestizaje. El tono reivindicativo en estos versos es sugerido; veremos cómo en breve cobrará más fuerza y sentido. Sigue la reseña de la

\footnotetext{
${ }^{6}$ La figura de santa Bárbara fue frecuentemente utilizada en las comedias de santos a través de los siglos, dificultándose la identificación de la obra aquí mencionada.

${ }^{7}$ Probable referencia al color de la piel. Escribe Benito Remigio Noydens en 1660: «Es señal conocida que uno está hechizado cuando al enfermo se le ha trocado el color natural en pardo y color de cedro» (apud Cruz Casado, 1992: 99).

${ }^{8}$ AGN, Inquisición, vol. 476, sin exp., fol. 246r.
} 
obra tomando visos de burla, ya que, al parecer, durante el espectáculo no todo sucedió según lo planeado:

Se cayó de la tramoya

un ángel por su ignorancia,

con tan impropia postura

que se puso [a] andar a gatas 9 .

Y así varios otros accidentes parecidos: se bosqueja un ambiente general de chabacanería y escasa profesionalidad. Entre el desorden general, no podía faltar el desorden de las costumbres, en la desenvoltura de un ambiente sincrético que trae a santa Bárbara a la corte de Moctezuma. Aparece una molendera que, si por un lado era un miembro indispensable de la servidumbre de una casa noble prehispánica, por el otro abreva del sustrato erótico, folclórico y literario, del personaje europeo de la molinera de copla y entremés:
Y, haciendo la molendera
de Moctesuma, alargaba
una pierna sin recato,
para que se la abrazaran ${ }^{10}$.

Sin embargo, algo, o más bien alguien, se salva en esa representación y salva la representación misma: es Manuelita, la Lechuga. Este romance se inserta, con toda probabilidad, en alguna controversia en curso, más o menos poética, alrededor de la compañía o bien de esa representación en especial: de ahí la alusión a unas «murmuraciones villanas» que andaban circulando. La Lechuga reivindica su papel en calidad de nada menos que figura de orgullo patrio, aunque aquí se hable de patria chica, es decir, de la ciudad de Puebla:

Como también la destresa, el primor, acierto y gala, con que dio la Lec[h]uguita nuebo crédito a su patria.

Piensen bien las que pretenden murmuraciones villanas, que aún las cosas que motejan no han de poder igualarlas. Pues, a no dar el remedio la havilidad extremada de Manuelita, perdida obra tan buena se hayara. Y assí la inutilidad, la insuficiencia, jactancia, la locura, la osadía con que todas estas hablan, tenga enmienda, porque pueda[n], si adquirir pretenden fama, para correjir sus yerros

${ }^{9}$ AGN, Inquisición, vol. 476, sin exp., fol. 246r.

${ }^{10}$ AGN, Inquisición, vol. 476, sin exp., fol. 246v. 
aprender de las poblanas ${ }^{11}$.

«Aprender de las poblanas», como poblana será la china que se empezará a ir gestando unos poco años después, en el trascurso del turbulento siglo XIX, para después ya entrar en el XX como símbolo nacional plenamente fraguado. La mujer del pueblo gallarda, desparpajada, respondona y orgullosa (de su terruño, de su color mestizo de cedro, de su oficio, de su lugar en el mundo) que aparecerá en los poemas de Guillermo Prieto y las novelas de Manuel Payno abreva, a su vez, en personajes dieciochescos como esta altanera actriz. Quien, por cierto, entre sus poemas de amor guarda estas pícaras (y deliciosas) cuartetas hexasilábicas, en las que la celebración del mestizaje, sin perder una pizca de orgullo, se vuelve más íntima y amorosa, y a su vez el amor deja la cursilería amanerada para plasmarse en unos versos tan sensuales como sencillos y hasta, de alguna manera, ingenuos. Tópicos como el lucero, el jardín florido o el coral comparten poder de evocación metafórica con comidas (el jamón) y objetos cotidianos (el salero). Los diminutivos, que ya se van afirmando como característicos del español americano, subrayan tanto lo coloquial como lo tierno del tono del poema. La china así le canta a su chino:
Yo tengo un chino $^{12}$ ques como jamón, que tiene un salero a la perfecsión.
Los ojos que tiene parenzen $[s i c]$ luseros, que quando los abre me muero por ellos.
Tiene un colorsito, aunque trigueñito; un coral pareze su bello osiquito.
E visto quartones ${ }^{13}$ a quales mexores, pero sí mi chino es jardín de flores ${ }^{14}$.

Chino y cuarterón son ejemplos de los intentos de definición de los matices del mestizaje americano. Su trayectoria semántica muestra aquí haber recorrido caminos de resignificación constante, desde el estigma despectivo, pasando por las escenas de las series de pinturas de castas no exentas de cierta mirada sensual-exotista (con toda la carga que la tradición española medieval proyecta sobre la figura de la morena) entrelazada a cierta búsqueda y afirmación de entrañable familiaridad, misma que intervendrá también en la pintura costumbrista decimonónica, y que se manifiesta en estos versitos de amor,

\footnotetext{
${ }^{11}$ AGN, Inquisición, vol. 476, sin exp., fol. 246r.

12 Chino significa 'mestizo' y/o 'de pelo rizado', y es también un apelativo cariñoso.

13 «Quarterón. Se llama en Indias al hijo de mestizo y española, o de español y mestiza, por tener un quarto de indio y tres de español» (Aut.).

${ }^{14}$ AGN, Inquisición, vol. 476, sin exp., fol. 248r.
} 
o deseo, a ambos. Manuelita, la Lechuga, se sacude de encima el papel pasivo de objeto de la mirada, resignifica a su gusto y parecer la catalogación de las pinturas de castas, en su escritura se adueña de esa voz femenina que - Mariana Masera docet - le viene del linaje de las muchachas rebeldes de la tradición medieval hispánica, y se planta en el escenario, espacio privilegiado de proyección simbólica, prefigurando, ¿sin saberlo? la representación de una nueva época.

\section{ÍNDICE DE FIGURAS}

Figura 1: Portada de Le donne vendicate. 1764. Venezia: Modesto Fenzo.

Figura 2: Portada de L'olimpiade. 1763. Padova: s/e.

Figura 3: Portada de La sposa fedele / La esposa fiel. 1772. Cádiz: Manuel Espinosa.

Figura 4: Entremés titulado El alcalde Chamorro. S/f. AGN, Indiferente Virreinal, caja 1262, exp. 9, fols. 1r.

Figura 5: Portada del Entremés de las cortesías. S/f. AGN, Indiferente Virreinal, caja 2788, exp. 5, fol. 1r.

Figura 6: Portada del Entremés de las cortesías. S/f. Barcelona: Imprenta de Pedro Escuder.

Figura 7: El poema de la Inesilla. Olavarría y Ferrari, 1961: 168.

Figura 8: Los papeles de la Lechuga. AGN, Inquisición, vol. 476, sin exp.

\section{ARCHIVOS CONSULTADOS}

AGN $=$ Archivo General de la Nación (México)

$\mathrm{BN}-\mathrm{FR}=$ Fondo Reservado de la Biblioteca Nacional (México)

\section{BIBLIOGRAFÍA}

Cruz Casado, Antonio (1992): «Auristela hechizada: Un caso de maleficia en el Persiles». Cervantes: Bulletin of the Cervantes Society of America, XVII-2, pp. 91-104.

OlAVARRÍA y FERRARI, Enrique de (1961): Reseña histórica del teatro en México 15381911. Tomo I, México: Porrúa.

ViQueIRA Albán, Juan Pedro (2001): ¿Relajados o reprimidos? Diversiones públicas y vida social en la ciudad de México durante el Siglo de las Luces, México: FCE.

VIVERos, Germán (1996): Talía novohispana. Espectáculos, temas y textos teatrales dieciochescos, México: UNAM. 


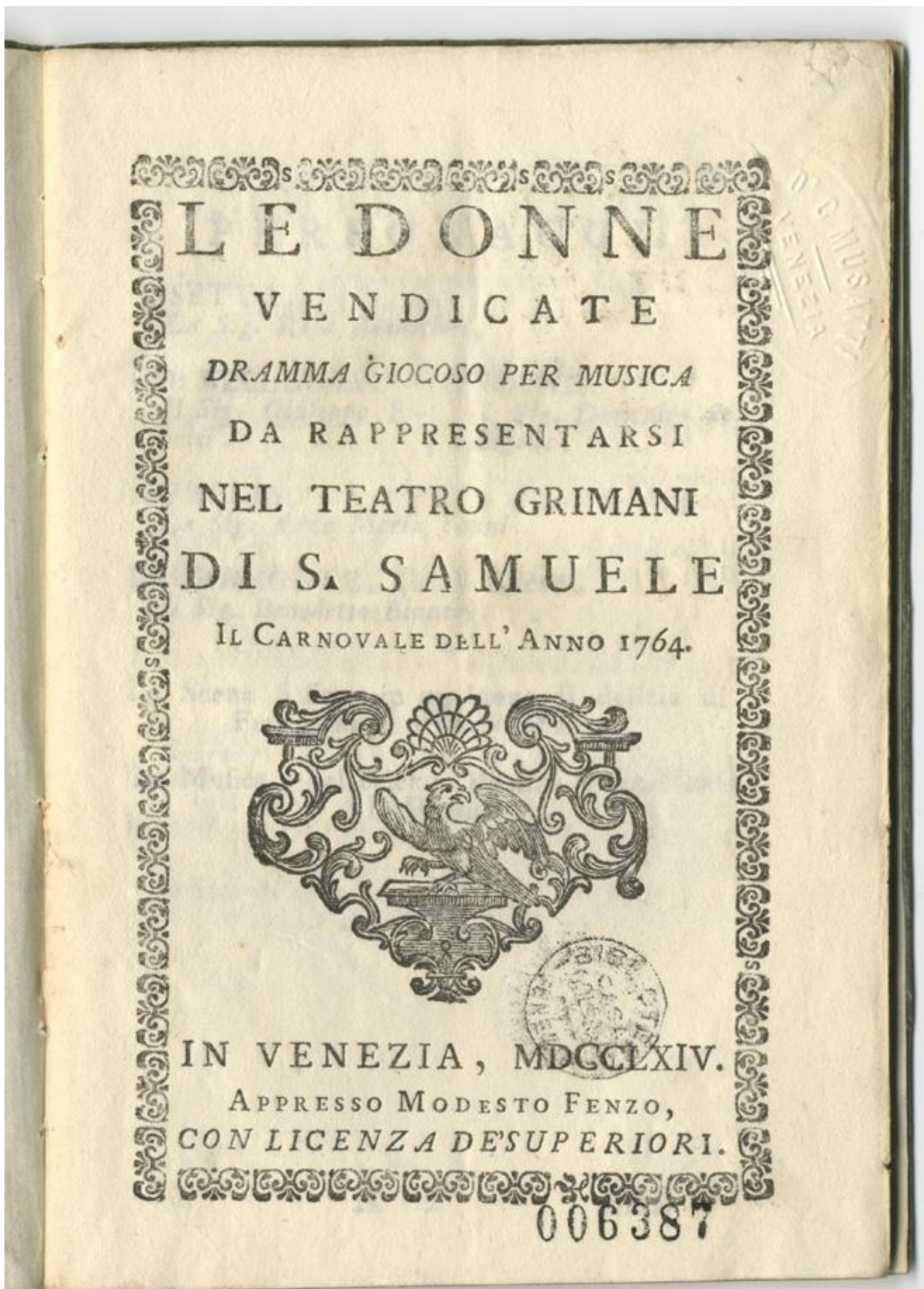

[Figura 1] 


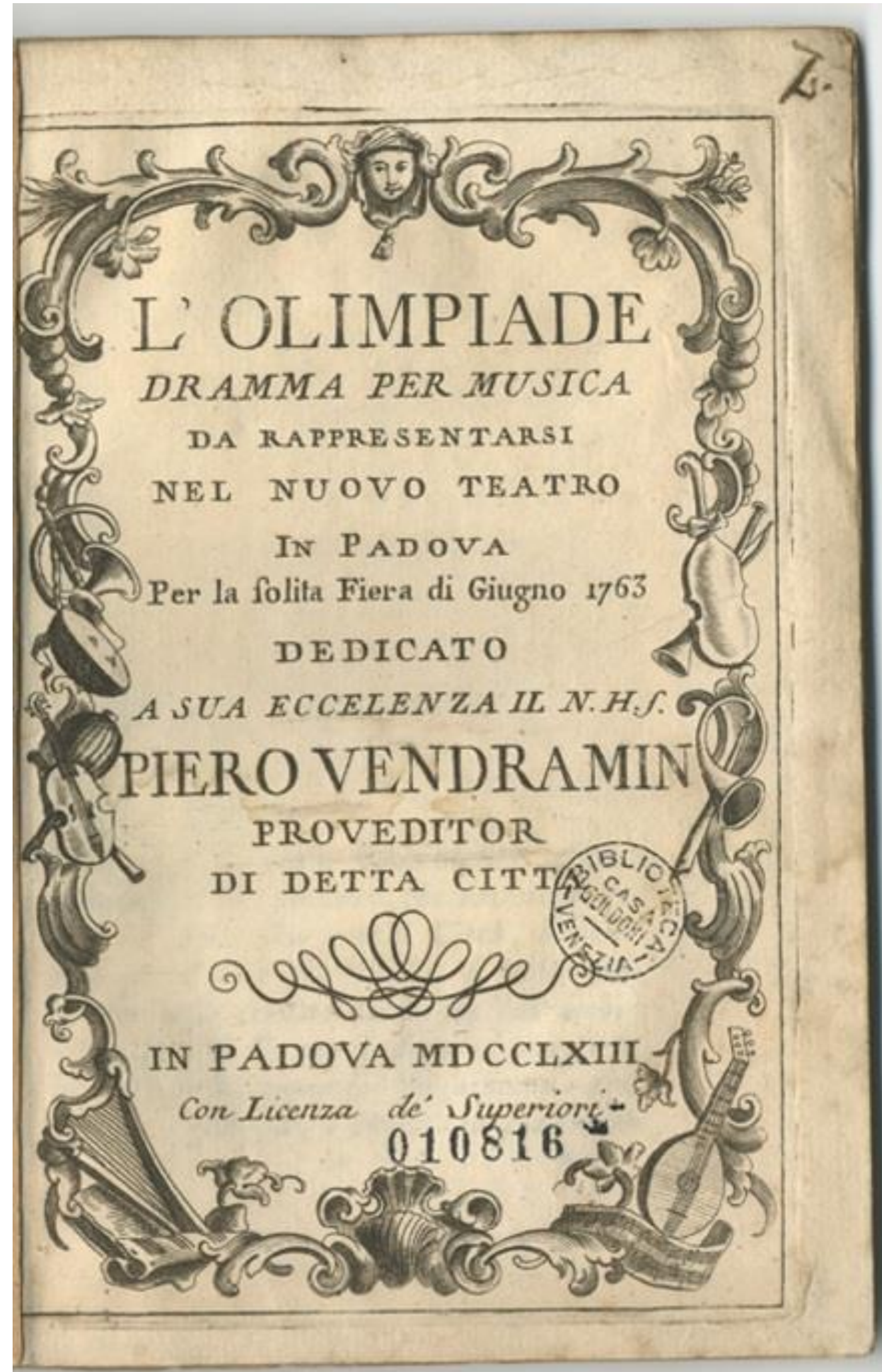

[Figura 2] 


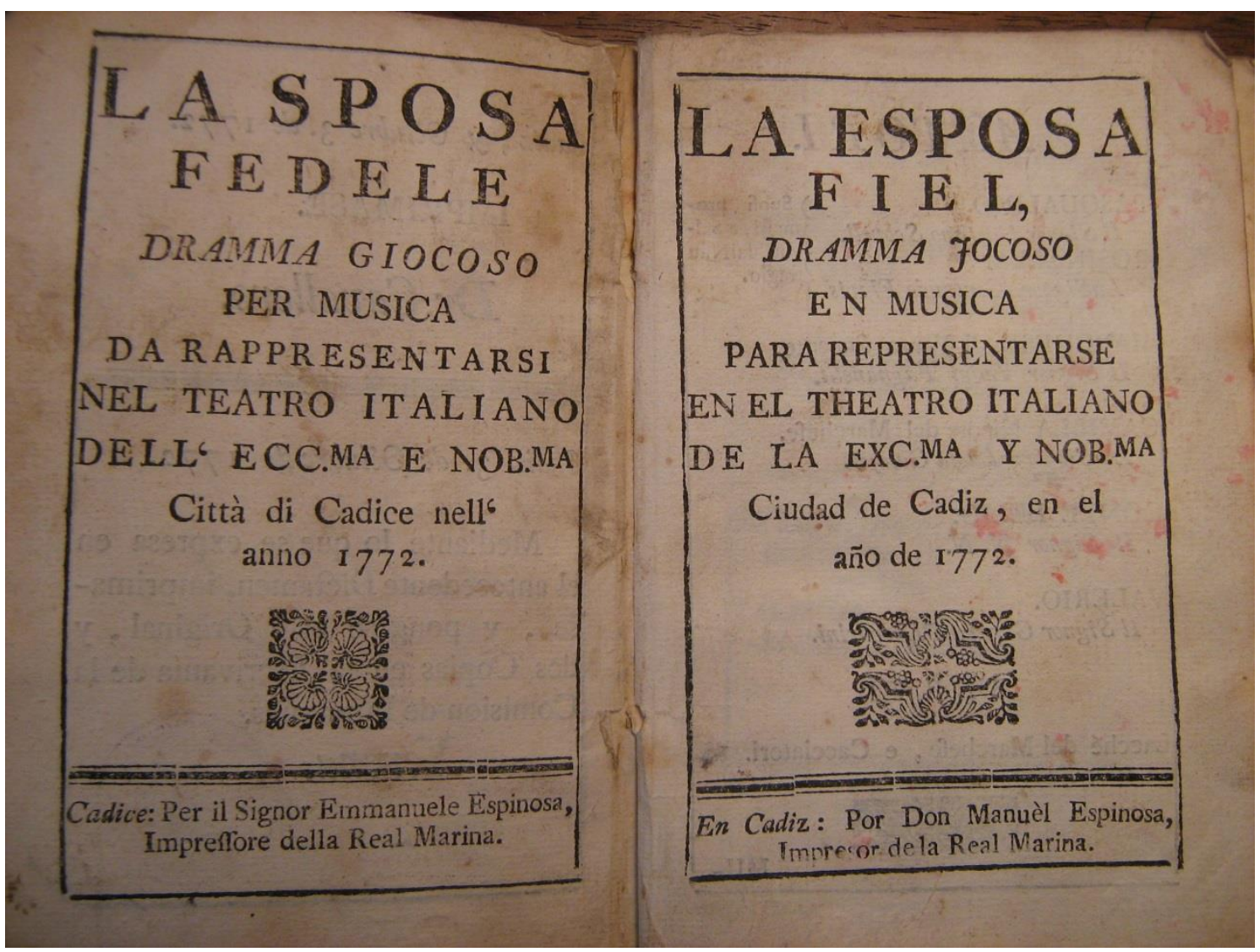

[Figura 3]

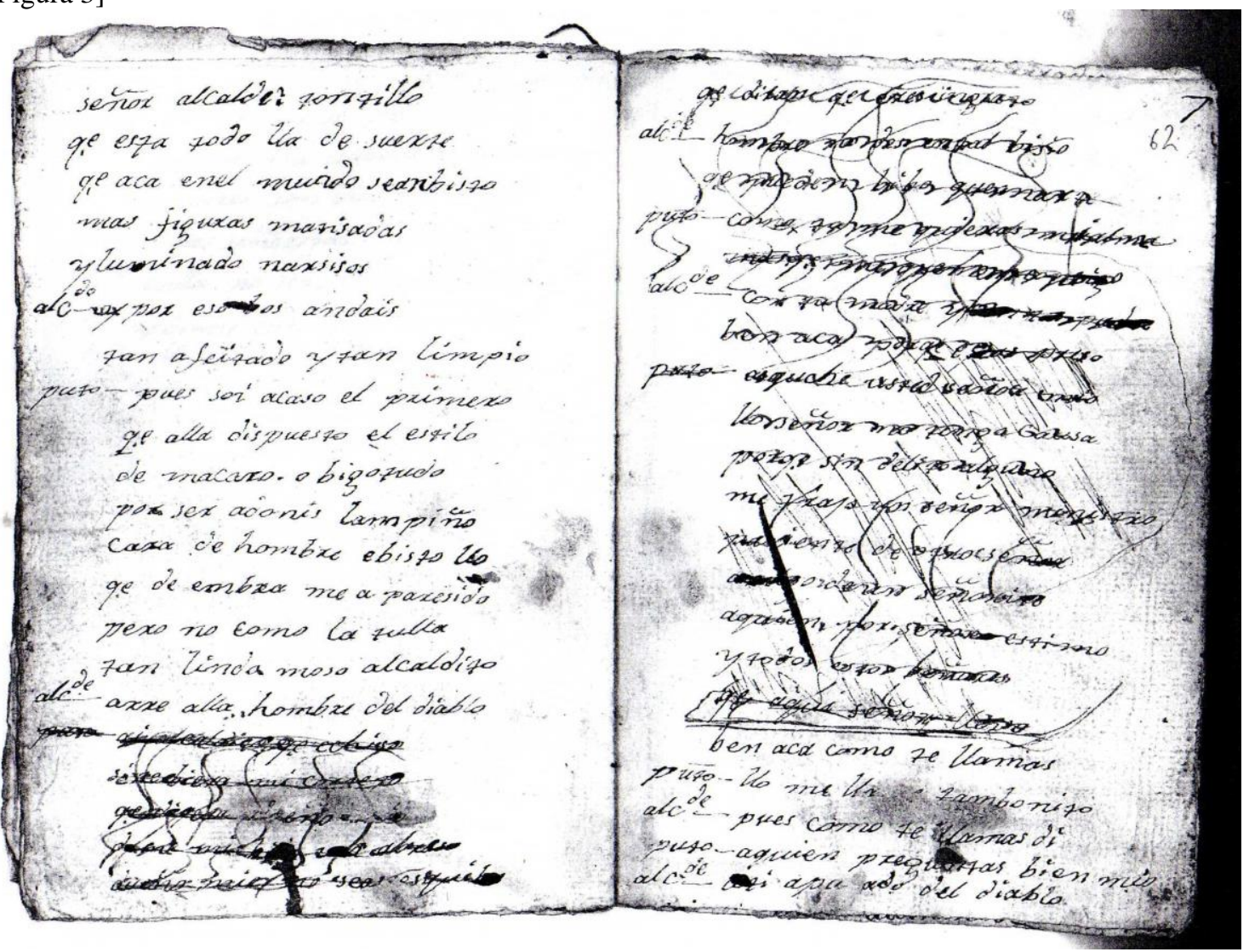

[Figura 4] 


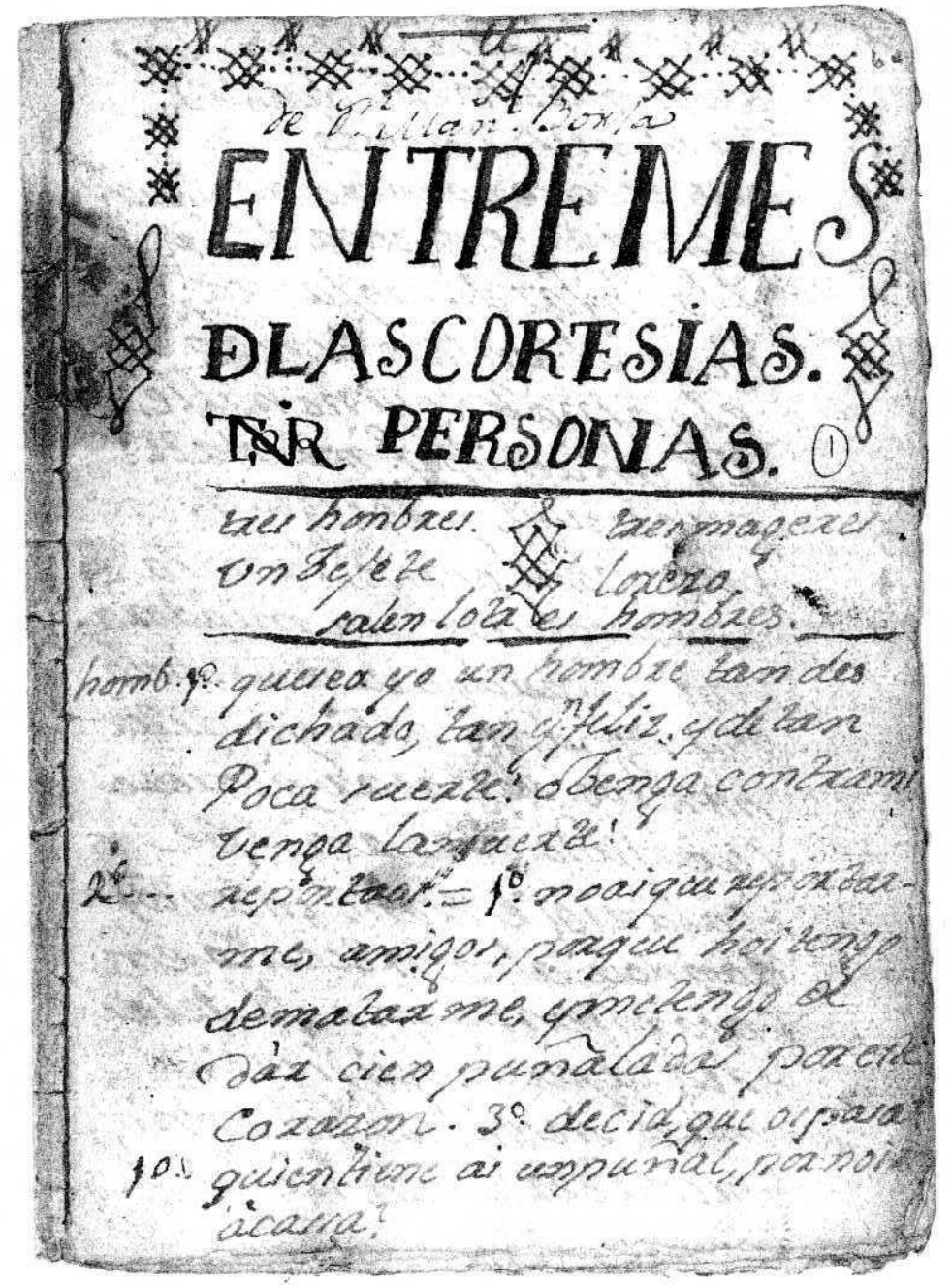

[Figura 5] 


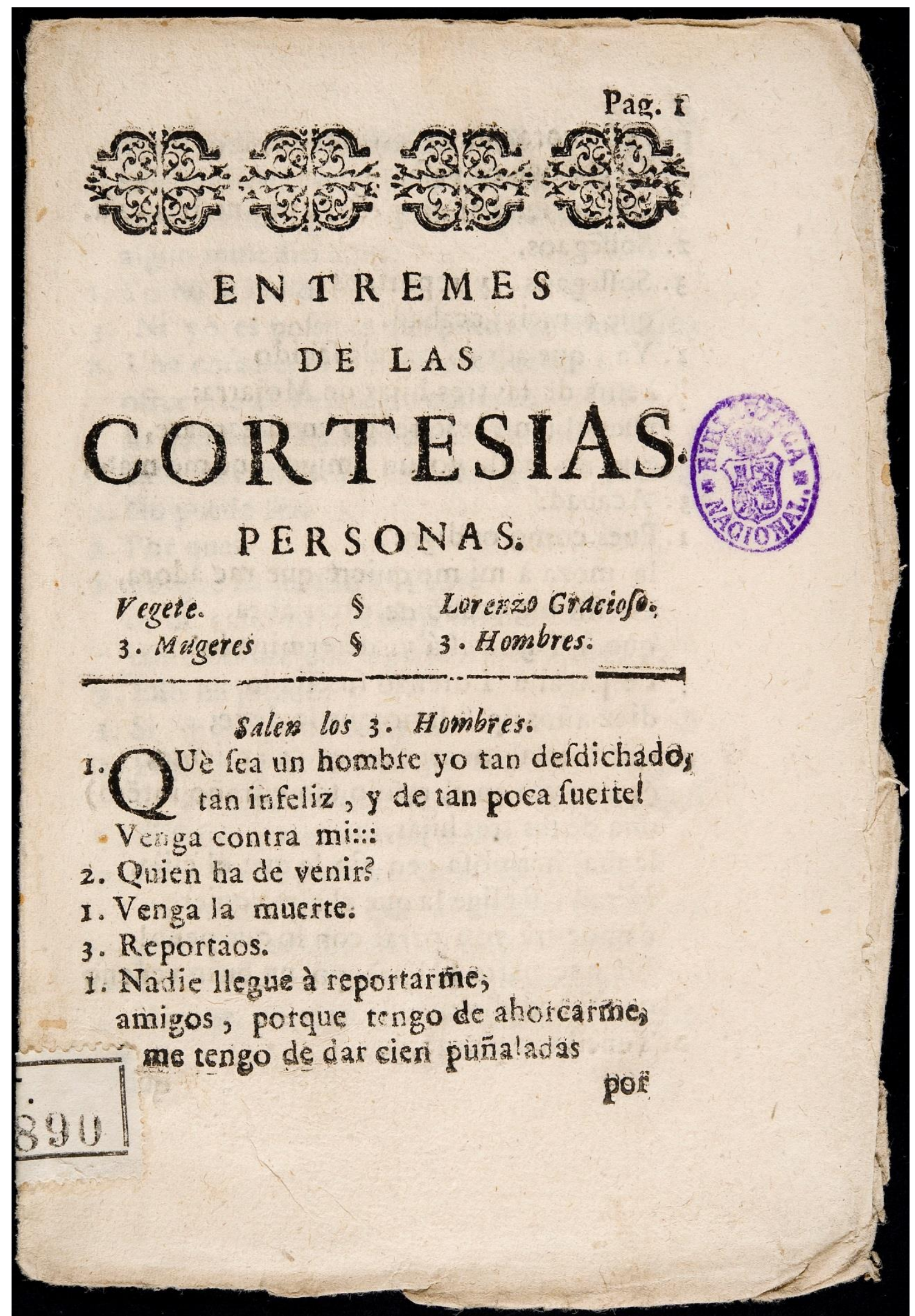

[Figura 6] 
vesarosa mi dicha, ¿nir quisiera ๘oluntad y posibles, Tujo y grandeza -así lograra

Donociesen mi afecto

Omi eficacia.

$\varpi$ ien encuentro que inútil

$\mathrm{I}_{\mathrm{n}}$ todo he sido

Zo es esta culpa mía

-es mi destino

Qustosa advierte

Zorte en vuestras piedades

Oy otra suerte $\nabla \mathbf{i}$ dudos

Zo tan feliz dí

iva harí

$\nabla_{\mathrm{i}}$ acción más generos

$\nabla_{\mathrm{e}} \mathrm{mi}$ fe amoros

Fn mi porfí

ßas en tal maní

Ars y ocios

خerxes con la Greci

-maginad

Somo me despreci Oh corte venerad Non que apreci Tra beneficiad

[Figura 7]

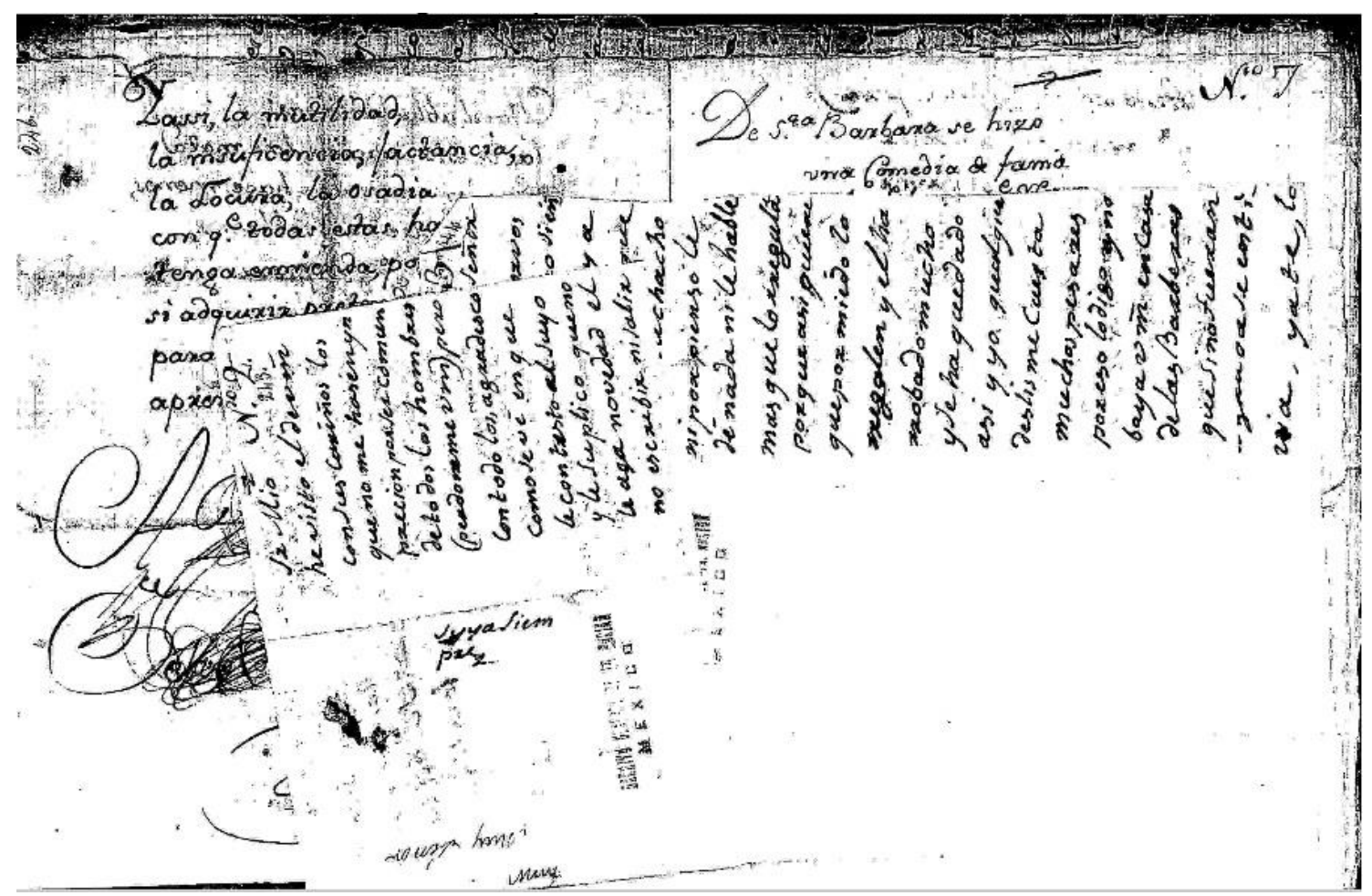

[Figura 8]

Fecha de recepción: 29 de agosto de 2019

Fecha de aceptación: 4 de septiembre de 2019

\section{9}

